O'Hara, J., Brown, M., McNamara, G., \& Shevlin, P. (2020). The Potential, Limitations and Evaluation of Education Networks in a Monocentric System. Revista de Investigación Educativa, 38(1), 33-52.

DOI: http://dx.doi.org/10.6018/rie.397201

\title{
The Potential, Limitations and Evaluation of Education Networks in a Monocentric System
}

\section{Potencial, Limitaciones y Evaluación de las Redes Escolares en un Sistema Monocéntrico}

\author{
Joe O'Hara, Martin Brown, Gerry McNamara and Paddy Shevlin \\ EQI, the Centre for Evaluation, Quality and Inspection, DCU Institute of Education, Ireland
}

\begin{abstract}
In almost all education systems, there has been an increasingly incentivised drive to establish and promote local education networks. In the case of Ireland, funded education networks referred to as 'education clusters' have been set up to allow schools to collaborate to increase innovation capacity as well as enhance the return on educational investment through economies of scale. While commendable in theory, there is nevertheless, limited evidence relating to the priorities of these networks as perceived by those who are at the core of them, namely teachers. There is also limited research relating to who should be involved in setting evaluation methodologies and standards for the network. As such, using Ireland as a case example, our study was guided by three interconnected questions; what should the priorities of education networks be, what are the benefits and challenges for such priorities and who should be involved in the development of evaluation methodologies and standards?

Findings, many of which we suggest have considerable relevance to most education systems, reveal that, while in theory, although the appeal of education networks in the form of enhanced professional capital is evident, there are still many issues that need to be resolved to enable such networks to deliver on their theoretical possibilities. These include the limitations of reciprocity among network members and the need for facilitated supports to moderate the competitive nature of schools in a network, allowing for competitive collaboration to occur. Importantly,
\end{abstract}

Correspondencia: Joe O’Hara, joe.ohara@dcu.ie, EQI, the Centre for Evaluation, Quality and Inspection, DCU Institute of Education, Dublin, 9, Ireland. 
in this research a significant majority of school principals did not see or were not favourable to the idea of education networks being used for cost reductions through economies of scale.

Keywords: Governance; School Networks; Evaluation Standards; Professional Capital.

\section{Resumen}

En casi todos los sistemas educativos cada vez se incentiva más el interés por establecer y promover redes educativas locales. En el caso de Irlanda, se han establecido redes educativas financiadas conocidas como 'education clusters' fomentar la colaboración entre centros educativos con el objetivo de mejorar su capacidad innovadora, así como la rentabilidad de la inversión educativa a través de economías de escala. Aunque este enfoque es meritorio en teoría, existen limitadas evidencias acerca de cómo los integrantes de estas redes perciben sus prioridades. También existen pocas investigaciones sobre quién debería delimitar las metodologías y estándares de evaluación para las redes. Así, nuestro estudio está guiado por tres cuestiones interconectadas, respondidas utilizando el caso irlandés como ejemplo: cuáles deberían ser las prioridades de la red, cuáles son los beneficios y retos de dichas prioridades, y quién debería implicarse en el desarrollo de su evaluación.

Los hallazgos revelan que, aunque en teoría los beneficios de las redes educativas relacionados con la mejora del capital profesional son evidentes, todavía hay muchas cuestiones que resolver para conseguir que las redes sean capaces de generar dichos beneficios. Estas incluyen las limitaciones de la reciprocidad entre los miembros de las redes y la necesidad de apoyos para moderar la naturaleza competitiva de los centros educativos dentro de una red, permitiendo de esta manera la existencia de una colaboración competitiva. En esta investigación, una mayoría significativa de directores de centro no estaban de acuerdo con la idea de utilizar las redes educativas como un mecanismo de reducción de costes a través de las economías de escala.

Palabras clave: Gestión; Redes Escolares; Estándares de Evaluación; Capital Profesional.

\section{Introduction}

In almost all education systems, there has been an increasingly incentivised drive to establish and promote local education networks (Organisation for Economic Cooperation and Development [OECD], 2015). The overarching imperative for the creation of such networks is that there are limitations to centralised, hierarchical command and control systems that are unable to respond to or cope with the increasingly complex demands of education (OECD, 2012). The appeal of education networks is frequently based on several overlapping concepts. At a local level, networks have the potential to catalyse improvement for those schools which require further innovation (Smith \& Wohlstetter, 2001) and which do not have the capacity to improve if working in isolation (Wohlstetter, Malloy, Chau, \& Polhemus, 2003). Networks are appealing as they can potentially allow for the efficient use of human and physical resources in a geographical location (Ehren \& Godfrey, 2017). Finally, the collective mass of such networks can act as a catalyst for innovation and change, not only in schools and local communities but also, it is suggested, in entire education systems (Barber, Chijioke, \& Mourshed, 2010; Rincón-Gallardo \& Fullan, 2016). In other words, networks have the potential to collectively enhance the 'social', 'human' and 'decisional' dimensions of 
what Hargreaves and Fullan (2012) refer to as 'professional capital'. They also have the potential to reduce the costs associated with educational provision through economies of scale (Department of Education and Skills [DES], 2018a).

These ideas are consistent with influential theories known collectively as 'new public governance' (Morgan \& Cook, 2015), and in consequence a significant volume of education networks have emerged in countries throughout Europe and elsewhere (Azorín, \& Muijs, 2017). In the case of the Netherlands, for example, education networks have been established to allow special and mainstream schools to work together to provide an inclusive education (Janssens \& Ehren, 2016). They have also been set up in areas such as Barcelona in Spain to reduce student absenteeism (Díaz-Gibson, Civís, Daly, Longás, \& Riera, 2017). Further afield, in Chile, school improvement networks have been set up throughout the country for school principals and administrators to share best practice and strategies for improvement (González, Pino, \& Ahumada, 2017). There are many other reported examples of education networks that have been established in other contexts, with varying evaluation standards and governance structures but with similar objectives (Hargreaves, \& Fullan, 2012; Lieberman, \& McLaughlin, 1992; McCormick, Fox, Carmichael, \& Procter, 2010).

In parallel, a constant theme throughout the often critical discourse of research into education networks is that the quality of outcomes derived from being part of a network initiative varies considerably and at times, it is challenging to ascertain if there has been any discernible improvements in student outcomes at all. In the case of the Netherlands for example, Prenger, Poortman, \& Handelzalts (2018) in their analysis of education networks found that there were only 'moderately positive effects on teachers' perceived satisfaction; the knowledge, skills, and attitude developed; and their application to practice' (p.1). Chapman's (2008) analysis of the relationship between 80 education networks and school improvement in England determined that there was no substantial gain in examination performance by those schools involved in the study. However, that research did suggest that there were a number of positive effects created by being part of the network, for example building capacity for school improvement, although the extent to which this occured varied considerably. Similarly, the Sammons, Mujtaba, Earl, \& Gu (2007) analysis of the Network Learning Communities (NLC) initiative in England concluded that 'while some schools and networks have shown marked improvement across a range of outcomes, the findings indicated that there is no overall NLC effect on attainment outcomes; rather, there is considerable variation at the school level within and between networks' (p.213).

Other research has tended to greater positivity about network outcomes such as enhanced inclusion (Chapman \& Hadfield, 2010), peer learning (Muijs, West \& Ainscow, 2010) and increased innovation capacity (Glazer \& Peurach, 2013). In the case of West Belfast in Northern Ireland, for example, there was a clear impact in the form of better transition arrangements from primary to post-primary schools as well as enhanced decision making to improve out of school supports (Brown, McNamara \& O'Hara, 2015). Hargreaves and Fullan (2012), present another promising example of the potential for school networks describing how Shanghai China has become one of the highest performing countries in the PISA/OECD literacy test scores and arguing that 'one of the ways they did this was to pair high-capacity schools with lower capacity schools and enable 
them to work together in a non-judgmental relationship'(p.142). By and large these researchers are in agreement that the success of networks occurs when they are carefully designed and based on previously described conditions for effective networks that have been reported in the literature. These include attention to the evaluation capacity and standards of the network (Brown et al., 2015); goal consensus (Provan \& Kenis, 2008), purpose and identity (Chapman \& Hadfield, 2010; Provan \& Kenis, 2008); reciprocity (Mooleanaar, 2010); and trust (Chapman \& Hadfield, 2009; Daly \& Finnigan, 2012).

Despite the considerable research reported above it is noteworthy that there is limited research relating to the perceptions and priorities of those who are, as it were, are at the receiving end of this new mode of governance, namely teachers. This is in part because, in many education systems, government-funded networks are limited to system-level priorities. In the case of Ireland for example, the more recently funded school networks initiative referred to as 'education clusters' finances schools to form collaborative networks which, in order to receive funding, are required to focus on government and transnational education priorities such as digital learning and STEM education (DES, 2018a).

In consequence this research, using Ireland as a case example, focussed on the views of schools and teachers regarding the possibilities and limitations of networking as perceived from their vantage point. The study was guided by a number of interconnected questions; what should the priorities of education networks be, what are the benefits and challenges for such priorities and who should be involved in the development of evaluation methodologies and standards for networks? To answer these questions, a sequential mixed-methods study (Creswell \& Clark, 2017) was carried out with a sample of post-primary school principals in Ireland. Data collection consisted of an electronic survey that was designed and subsequently sent to a proportionate sample of primary and post-primary school principals in Ireland. This was followed by a series of one-hour semi-structured interviews with principals from the various school types and regions in the Irish education system. Finally, data sets were converged to form an overall interpretation of the study.

The first part of this paper will offer an analysis of the rise of education networks in Ireland and how networks are increasingly perceived as a core instrument for innovation and change within the Irish education system. The second part of the paper describes the research design that was used in the study. Next, the presentation and analysis of research findings are described. Finally, the paper concludes with an overall interpretation of the previous stages of the research and discusses how the findings derived from this study have wider implications for policy reform at both a national and international level.

\section{The rise of Education Networks in Ireland}

As with most education systems, various government-funded education networks exist in Ireland. For example, the Department of Education has provided funding to a number of subject association networks in Ireland (DES, 2018b). The remit of such groups is not for local networks of schools to collaborate and evaluate an aspect of educational provision in an area, but rather 'to support the work of Teachers' Groups 
and Associations (TGAs) which afford Continuing Professional Development (CPD) and professional peer support.' (Teacher Professional Networks, 2017).

Recently however, and perhaps surprisingly because of Irelands highly centralised governance structures (OECD, 2019) education networks, referred to as 'local education clusters', have been established through a process of incentivised participation between schools in geographical education regions throughout Ireland (Department for Education and Skills, 2018). The purpose of these networks is similar to those of other established education networks in Europe, namely 'to improve student outcomes by sharing best practice and school improvement experiences, foster collaborative in and out-of-hours initiatives, staff peer mentoring and leadership, and cost reductions through economies of scale'(Government of Ireland, 2018). As stated by the Minister for Education at the launch of the initiative 'never before have schools been funded to work together on innovative solutions and given the freedom to experiment with new projects to see what works and what doesn't'. (DES, 2018a).

\section{The operation and implementation of Local Education Clusters in Ireland}

The overarching objective of education clusters is that it allows them to work together, in some cases with higher education institutions and enterprise, and experiment to find creative solutions to complex problems. Successful approaches can then be shared across the school sector' (DES, 2018a).

Local education clusters are required to focus on specific themes that are decided by the DES such as school leadership, STEM and digital learning (DES, 2018a). In the case of leadership the aims of the scheme are very similar to those of education networks in other jurisdictions such as the Area Learning Community in West Belfast (Brown et al., 2015) including 'strengthening school planning' and 'enabling schools to engage with the community and foster external partnerships' (Centre for School Leadership, 2018a). To receive funding, a group of schools is required to make a joint application detailing the project aims and the implementation and roles and responsibilities of the education cluster. The application also requires the cluster of schools to detail the project schedule, outcomes and deliverables as well as describing how the project will be evaluated and monitored (Centre for School Leadership, 2018b). Applications are then adjudicated on, using selection criteria, by a panel consisting of members of the Department of Education and Skills, the Centre for School Leadership, Education Centre Directors, and Third Level, Business/ Industry (Centre for School Leadership, 2018c). A maximum of two projects per education region is then selected to receive funding. If two applications receive the same mark, priority is given to those schools who have Disadvantaged School (DEIS) status. Similar application and selection procedures also exist for thematic clusters such as digital, STEM and creative learning clusters. Commendably, to ensure the success of the cluster, a number of stakeholders with specific supportive roles and responsibilities are also involved in the operations of the cluster such as a cluster coordinator, a facilitator, and where appropriate, personnel from Third level and Business. Other stakeholders, such as the Department of Education and Skills (DES) also have specific roles such as the evaluation of each project. 


\section{Evaluation of Local Clusters in Ireland}

A local education cluster is defined as 'a collection of between three and six schools which will collaborate in the design, delivery, evaluation and dissemination of the outcomes of these innovative projects' (Centre for School Leadership, 2018a). Surprisingly, given the above definition, which refers to evaluation, there is limited information relating to how these networks are to be evaluated. The application form for cluster funding merely asks applicants to provide a description of 'the cluster plans for how the project will be evaluated'(2018c). As regards, external evaluation of education clusters, while it is mentioned that the project will be externally evaluated no detailed description of what evaluation methodologies and standards will be used is outlined (2018d).

In addition, the description of the scheme only states that:

- The pilot scheme will be subject to an external evaluation, which will require the active participation of all cluster members. The evaluation will run for the project duration, with a report expected to issue by July 2020 (p.2)

- The Department is keen to learn from the project. To that end, participating schools will be expected to report regularly to the Department on progress made using a self-evaluation process (p.2)

- The project plan should include: a proposed evaluation and assessment model for the project, during (monitoring) and on completion (p.4)

The lack of clearly defined evaluation methodologies and standards is perhaps not surprising given that education networks are customarily associated with voluntarism. As Provan \& Kenis (2008) suggest, 'a common assumption is that, since networks are collaborative arrangements, governance, which implies hierarchy and control, is inappropriate' $(\mathrm{p}, 230)$. There is also, apart from the Erasmus+ PINS project, limited research relating to how the quality of network activities can be evaluated. Because of the complexity and voluntary nature of networks, evaluation research has in the main, tended to focus on individual schools (see, for example, Brown, McNamara, O'Hara, O’Brien \& Faddar, 2018; Ehren et al., 2013; McNamara \& O'Hara, 2012). However, Brown et al., (2015), among others advise that there needs to be clearly agreed network priorities, and clearly defined evaluation methodologies and standards, prior to the initiation of education networks. Otherwise, as has been the case with many education network initiatives, the quality of outcomes derived from education networks is diminished. The presentation and analysis section of this research addresses these issues.

\section{Method}

\section{Objectives}

Using a mixed-methods research design (Creswell \& Clark, 2017), the overarching objective of this study was to ascertain, as perceived by school principals, what the priorities of education networks should be as well as the benefits, challenges, methodologies and standards for the initiation and implementation of such networks. 


\section{Population and Sample}

This population and sample size consisted of two distinct groupings. Phase one of the research consisted of a review of the literature on education networks as summarised in the preceding sections of this study. Phase two of the research consisted of the distribution of a localised survey instrument that was developed as part of the Erasmus+ PINS project. The survey was distributed to a proportionate sample of primary and post-primary schools in Ireland based on geographical location and school type. The combined sample size was 335, representing approximately $10 \%$ of the total population of primary mainstream, special and post-primary schools in Ireland. Phase 3, of the research, consisted of a series of semi-structured interviews with a representative sample $(n=20)$ of principals based on $(1)$ the school level (Primary, Post Primary); (2) the type of primary and post-primary school (Mainstream, Special, Secondary, Vocational and Community Comprehensive); (3) the location of the school (Rural, Urban).

\section{Procedure and Analysis}

The first step of phase two of the research involved the localisation of the PINS survey instrument to the context of the Irish Education system. The first section of the survey required participants to answer a series of open-ended questions relating to the benefits, challenges, resource requirements and priorities of education clusters. The second section of the survey consisted of a series of ordinal bipolar response items (Not a priority, Low priority, Medium priority, High priority, Essential priority) that required participants to rate the priorities of education clusters. The final section of the survey required participants to rate what stakeholders should be involved in setting evaluation methodologies and standards. Each of these items received a score of 1 , $2,3,4,5$, for each response alternative. The second phase of the study consisted of a series of semi-structured interviews with a representative sample of principals. Analysis of ordinal response items was carried out using parametric and non-parametric statistical techniques. Analysis of open-ended questions derived from the survey and the semi-structured interviews employed Miles \& Huberman's (1994) 'Components of Data Analysis: Interactive Model'.

\section{Results}

This section provides an analysis of research findings related to the priorities of being part of a network as perceived by school principals in Ireland. The first section describes the priorities of the network in terms of enhancing 'human capital'. This is followed by school principals' perceptions of the purpose of school networks as they relate to enhancing the 'social' and 'decisional' dimensions of professional capital. The penultimate section provides an analysis of principals' perceptions of school networks to enhance human and infrastructural resources. Finally, an analysis of principals' perceptions of who should be involved in setting evaluation standards of the network is described. 


\section{Priorities of School Networks to enhance Human Capital}

In terms of the human capital derived from being part of a network and in line with Wenger's $(1998,2000)$ social theory of learning via communities of practice, a significant majority of principals $(73 \%$ ) who responded to the survey were of the view that schools learning from each other should be a high or essential priority of education networks (Table 1). Statements by two interview participants encapsulate the overarching benefits of being part of a network as perceived by nearly all interviewees, 'clusters are hugely beneficial for schools to learn from each other' and 'sharing and collaborating within schools is seen as essential. I believe that sharing across schools is also essential. We can learn from each other's successes and failures'.

Table 1

Priorities of the Networks to enhance Human Capital: Innovation and Improvement

\begin{tabular}{cccccc}
\hline Priority & $\begin{array}{c}\text { Not a } \\
\text { priority }\end{array}$ & $\begin{array}{c}\text { Low } \\
\text { Priority }\end{array}$ & $\begin{array}{c}\text { Medium } \\
\text { priority }\end{array}$ & $\begin{array}{c}\text { High } \\
\text { priority }\end{array}$ & $\begin{array}{c}\text { Essential } \\
\text { priority }\end{array}$ \\
\hline $\begin{array}{l}\text { To ensure that schools } \\
\text { learn from each other }\end{array}$ & $3.88 \%$ & $5.60 \%$ & $17.24 \%$ & $31.90 \%$ & $41.38 \%$ \\
\hline $\begin{array}{l}\text { To ensure that strong } \\
\text { schools support weak } \\
\text { schools in improving }\end{array}$ & $10.92 \%$ & $19.21 \%$ & $38.43 \%$ & $24.89 \%$ & $6.55 \%$ \\
\hline
\end{tabular}

Interestingly this positive view had clear limits.' The idea of networks being for the purpose of strong schools supporting weak schools, as was the case with the school network initiative in Shanghai China, (Hargreaves \& Fullan, 2012) was not strongly supported. Only a minority of principals (31\%) were of the view that a high or essential priority of the network should relate to that of strong schools supporting weak schools. In effect, as stated by one principal, 'it is relatively easy to start initiatives such as this, but when the workload takes over it is hard to keep initiatives like this one current, so it has to be very useful for us'. Another principal stated, 'education clusters should be of like, or likeminded schools, not geographical. A lack of familiarity with reality is evident in the thinking'. The notion of reciprocity as being transactional as described by Mooleanaar (2010) should, according to some principals, be emphasized in the process of network planning to a greater extent than notions of strong schools supporting weak schools in improving.

\section{Priorities of School Networks to enhance Social Capital}

In terms of education network priorities being to enable staff to jointly develop and provide continuous professional development (CPD), almost $77 \%$ of those who responded to the survey were of the view that the development and provision of CPD should be a high or essential priority of the network (Table 2). According to 
one participant, 'we can learn so much from each other by joint learning'. Another participant was of the view that network members developing and providing CPD would allow for "quality CPD to suit school demographics". Furthermore, participants were also of the view that the provision and development of CPD by members of the network would be more beneficial to schools in the network in comparison to externally provided CDP by as one participant put it, 'some who haven't been in a classroom for over a decade'. As an external CPD provider in Goodall, Day, Lindsay, Muijs, \& Harris (2005) states: 'It's not a model of injecting expertise into the schools from outside but rather liberating the expertise that's already there' (p.87). Participants' positive views on the benefits of network provided CPD was similar to that of teacher's in Lawlor (2014). 'This belief is rooted in teachers' experience of external CPD seminars which, though designed to facilitate a meaningful experience for teachers, include similar information and key messages for all participants regardless of context. Thus, it is clear that the provision of network designed and delivered CPD is seen to be a real positive of the networking process.' (p.227).

Table 2

Priorities of the Networks to enhance Social Capital: Continuous Professional Development

\begin{tabular}{lccccc}
\hline Priority & $\begin{array}{c}\text { Not a } \\
\text { priority }\end{array}$ & $\begin{array}{c}\text { Low } \\
\text { Priority }\end{array}$ & $\begin{array}{c}\text { Medium } \\
\text { priority }\end{array}$ & $\begin{array}{c}\text { High } \\
\text { priority }\end{array}$ & $\begin{array}{c}\text { Essential } \\
\text { priority }\end{array}$ \\
\hline $\begin{array}{l}\text { To jointly develop and pro- } \\
\text { vide continuous professional } \\
\text { development for teachers }\end{array}$ & $4.31 \%$ & $4.31 \%$ & $14.22 \%$ & $34.48 \%$ & $42.67 \%$ \\
\hline
\end{tabular}

In terms of the priorities of networks to provide inclusive education, there were mixed views among participants. Only a small majority (52\%) of principals were of the view that co-operation for the provision of inclusive education should be a high or essential priority of the network (Table 3). As stated by one positive participant, 'this will break down barriers between different schools and patrons. It may also begin to break down some of the segregation currently taking place because of patrons and the notion of choice'. There were, however, conflicting views in this area. These views related not so much to the pervasive commitments of teachers to provide an inclusive education but rather, the contextual and societal challenges as they apply to the different school types that exist in Ireland. The following comments illustrate this point.

Our school is a DEIS (disadvantaged) school with excellent teachers and with excellent kids who have very difficult circumstances outside of school. I would be wary of asking my staff to get together with teachers in the [Name of School deleted] as there could be a chance that our far more inclusive work and better funding for dealing with disadvantage could be compromised). 
Table 3

Priorities of the Networks to enhance Social Capital: Inclusive Education

\begin{tabular}{lccccc}
\hline Priority & $\begin{array}{c}\text { Not a } \\
\text { priority }\end{array}$ & $\begin{array}{c}\text { Low } \\
\text { Priority }\end{array}$ & $\begin{array}{c}\text { Medium } \\
\text { priority }\end{array}$ & $\begin{array}{c}\text { High } \\
\text { priority }\end{array}$ & $\begin{array}{c}\text { Essential } \\
\text { priority }\end{array}$ \\
\hline $\begin{array}{l}\text { To provide inclusive } \\
\text { education }\end{array}$ & $7.86 \%$ & $10.04 \%$ & $30.13 \%$ & $33.62 \%$ & $18.34 \%$ \\
\hline
\end{tabular}

In terms of education networks for staff to jointly develop and offer curricula, almost $47 \%$ of those who responded to the survey were of the view that the development and offering of common curricula should be a high or essential priority of the network (Table 4). As stated by one participant, 'I'm not sure about developing curricula, but it's a good idea if we didn't have enough numbers to offer a subject'. Another participant stated:

Logistically I can see many challenges, but the development of short courses by a local network of schools on something like local studies or some other course that's meaningful to the schools in the town, now that would be very interesting for students and teachers, and they could learn a lot from each other. Again though, timetabling, getting teachers together, a lot of work is needed for this, and we'd need a lot of support for class cover, etc.

However, in keeping with previous statements relating to the competitive nature of schools in Ireland, some other principals were of the view that developing subjects together sounds great and all but not all schools want to share anything. We are all competing for students, so this network has to be beneficial for everyone and not weaken a school in any way'. Indeed, as stated by Katz \& Earl (2007), 'determining a focus involves more than choosing a "good" idea or someone's pet initiative. Networked learning communities need to choose the "right" focus for the participating schools, given their particular context and history and what is known explicitly about innovations that are high leverage in fostering student learning' (p.3).

A minority of principals (43\%) were also of the view that a high or essential priority of the network should be to develop joint assessments. According to one principal, 'it would increase the culture of witnessing good practice, trying out new assessment methodologies, learning to trust one's peers to evaluate one's teaching, being answerable to others'. Another principal stated, 'so we've moved into teachers assessing students work with the new Junior Cert [Lower Secondary level Curriculum], so I suppose teachers looking at how other teachers assess their students in other schools is a good idea'.

Conversely, and confirming the view of the OECD (2019) that 'the patterns for Ireland show very low levels of virtually all dimensions of local autonomy' (OECD 2019, p.69), a number of principals were of the view that teachers developing joint assessments in a network would be challenging given that, it is only since 2016 that teachers in Irish post-primary schools have been required to assess students course-based work for State examinations. The following comments illustrate this point. 'Yes, it is a good 
idea, developing joint assessments, but they [teachers in a school] find it difficult to do this. Now doing it in a network of schools. I don't think that we are ready for this just yet'. Another principal stated, 'yes with AFL [Assessment for Learning] as schools can learn a lot from each other but no, not when it comes to marking students'.

Table 4

Priorities of the Networks to enhance Human Capital: Curriculum Development and Assessment

\begin{tabular}{lccccc}
\hline Priority & $\begin{array}{c}\text { Not a } \\
\text { priority }\end{array}$ & $\begin{array}{c}\text { Low } \\
\text { Priority }\end{array}$ & $\begin{array}{c}\text { Medium } \\
\text { priority }\end{array}$ & $\begin{array}{c}\text { High } \\
\text { priority }\end{array}$ & $\begin{array}{c}\text { Essential } \\
\text { priority }\end{array}$ \\
\hline $\begin{array}{l}\text { To jointly develop } \\
\text { and offer curricula }\end{array}$ & $13.48 \%$ & $13.48 \%$ & $26.09 \%$ & $28.70 \%$ & $18.26 \%$ \\
\hline To develop joint & 31 & 31 & 60 & 66 & 42 \\
assessments & $11.95 \%$ & $15.04 \%$ & $29.20 \%$ & $30.53 \%$ & $13.27 \%$ \\
\hline
\end{tabular}

\section{Priorities of School Networks to enhance Decisional Capital}

Regarding utilising school networks to enhance decisional capital, almost $56 \%$ of those principals who responded to the survey were of the view that jointly evaluating an aspect of educational provision (e.g. literacy) in the area, should be a high or essential priority of the network. Similar perspectives relating to the priorities of a network to jointly develop an improvement plan for an aspect of educational provision were also offered (Table 5). According to one principal whose school has already collaborated with other schools in the area, 'we already had a look at evaluation cluster arrangements in our area, and it works really well. Teachers really value advice from their colleagues'. Another principal in relation to the sharing of expertise for the evaluation of newly qualified teachers in the area stated, 'contrary to the Droichead approach [A government devised programme for the induction of newly qualified teachers in Ireland] which fosters school isolation in the evaluation of newly qualified teachers, Local Education Clusters could be a force for good in promoting collegiality and the sharing of expertise and experience'.

Despite the above comments, some principals were also of the view that there are significant challenges to the implementation of such a process. One participant stated that 'all schools do SSE [School Self Evaluation] and have plans for improvement in literacy and numeracy and we get what it's all about, but it's taken us a long time to get there. Are we ready to start doing this with other schools now?' Another principal was hesitant to engage in network evaluation and planning based on her experience of government-mandated SSE in Ireland that required schools to evaluate literacy, numeracy and one other aspect of teaching and learning over a three-year period (DES, 2012). 'I mean, who will set the agenda for all of this. When I heard about SSE first, I thought it was a brilliant idea, schools evaluating themselves. Then what happened? We were told we must evaluate literacy and numeracy and something else. Is this going to happen again?' Another principal took a somewhat impartial view of network 
evaluation and planning. 'Yes, it's a good idea, but you would want to be very careful about what's going to be evaluated and who is going to coordinate it all'.

This is an important point about the success or failure networks being dependent on the degree of autonomy given to pursue areas of interest of interest to and chosen by the members. This was shown in West Belfast where a defining factor for the success of the network was that the aspect of education to be evaluated was relevant to all schools and moderated by the district inspector as a critical friend and facilitator of the process (Brown et al., 2015).

Table 5

Networks to enhance Decisional Capital: Evaluation and Planning

\begin{tabular}{lccccc}
\hline Priority & $\begin{array}{c}\text { Not a } \\
\text { priority }\end{array}$ & $\begin{array}{c}\text { Low } \\
\text { Priority }\end{array}$ & $\begin{array}{c}\text { Medium } \\
\text { priority }\end{array}$ & $\begin{array}{c}\text { High } \\
\text { priority }\end{array}$ & $\begin{array}{c}\text { Essential } \\
\text { priority }\end{array}$ \\
\hline $\begin{array}{l}\text { To jointly evaluate an aspect } \\
\text { of educational provision } \\
\text { (e.g. literacy) in the area }\end{array}$ & $8.23 \%$ & $9.96 \%$ & $25.97 \%$ & $36.36 \%$ & $19.48 \%$ \\
\hline $\begin{array}{l}\text { To jointly develop an im- } \\
\text { provement plan for an aspect } \\
\text { of educational provision } \\
\text { (e.g. literacy) in the area }\end{array}$ & 19 & 23 & 60 & 84 & 45 \\
\hline
\end{tabular}

\section{Priorities of School Networks to Enhance Economies of Scale}

When asked about networks sharing infrastructural resources, almost $47 \%$ of those who responded to the survey were of the view that the sharing of IT resources should be a high or essential priority of the networks. As shown in table 6, support for networks for the purpose of sharing school buildings was considerably less (13\%). Whilst some principals saw the benefits of sharing infrastructural resources, e.g. sports facilities, most principals were of the view that networks for the purpose of sharing school buildings and school grounds would be above the remit of education clusters. This was also the case with the sharing of human resources (Table 7).

Table 6

Priorities of the Network to enhance Economies of Scale: Infrastructural Resources

\begin{tabular}{lccccc}
\hline Priority & $\begin{array}{c}\text { Not a } \\
\text { priority }\end{array}$ & $\begin{array}{c}\text { Low } \\
\text { Priority }\end{array}$ & $\begin{array}{c}\text { Medium } \\
\text { priority }\end{array}$ & $\begin{array}{c}\text { High } \\
\text { priority }\end{array}$ & $\begin{array}{c}\text { Essential } \\
\text { priority }\end{array}$ \\
\hline \multirow{2}{*}{ To share resources: IT } & $7.89 \%$ & $14.47 \%$ & $31.14 \%$ & $32.46 \%$ & $14.04 \%$ \\
& 18 & 33 & 71 & 74 & 32 \\
\hline
\end{tabular}




\begin{tabular}{lccccc}
\hline Priority & $\begin{array}{c}\text { Not a } \\
\text { priority }\end{array}$ & $\begin{array}{c}\text { Low } \\
\text { Priority }\end{array}$ & $\begin{array}{c}\text { Medium } \\
\text { priority }\end{array}$ & $\begin{array}{c}\text { High } \\
\text { priority }\end{array}$ & $\begin{array}{c}\text { Essential } \\
\text { priority }\end{array}$ \\
\hline $\begin{array}{l}\text { To share school } \\
\text { buildings and school } \\
\text { grounds }\end{array}$ & $31.30 \%$ & $23.91 \%$ & $31.30 \%$ & $12.17 \%$ & $1.30 \%$ \\
\hline
\end{tabular}

Apart from the sharing of, for example, community workers and psychological support services, the majority of principals were of the view that schools sharing human resources should not be a significant priority of the network. As illustrated in the following comments, a number of principals saw some benefits of networks for the purpose of sharing human resources, 'accessing special deals on school infrastructural needs or resources, as well as legal or financial needs'; 'they may also lead to an increased sharing of load regarding SEN (Special Education Needs) placement'. Interestingly however, in the majority of cases, as illustrated in the following comments, principals were resistant to the idea of school networks for the purpose of sharing teachers, 'schools are in competition, and I'm hardly going to share my best teachers with another school, now am I?'; 'we are already being asked to do more with a lot less. Who comes up with these ideas, certainly not anyone who knows how a school works'.

These responses are interesting in that they imply strict limitations on the range of activities which school leaders see as appropriate to hand over to networks.

Table 7

Priorities of the Network to enhance Economies of Scale: Human Resources

\begin{tabular}{lccccc}
\hline Priority & $\begin{array}{c}\text { Not a } \\
\text { priority }\end{array}$ & $\begin{array}{c}\text { Low Prior- } \\
\text { ity }\end{array}$ & $\begin{array}{c}\text { Medium } \\
\text { priority }\end{array}$ & $\begin{array}{c}\text { High pri- } \\
\text { ority }\end{array}$ & $\begin{array}{c}\text { Essential } \\
\text { priority }\end{array}$ \\
\hline $\begin{array}{l}\text { To share community } \\
\text { workers and support } \\
\text { services (e.g. school } \\
\text { psychologist) }\end{array}$ & $5.63 \%$ & $9.09 \%$ & $18.61 \%$ & $38.10 \%$ & $28.57 \%$ \\
\hline $\begin{array}{l}\text { To share staff } \\
\text { (e.g. teachers) }\end{array}$ & 13 & 21 & 43 & 88 & 66 \\
\hline $\begin{array}{l}\text { To share resources: } \\
\text { HR services }\end{array}$ & $18.06 \%$ & $17.18 \%$ & $36.56 \%$ & $22.03 \%$ & $6.17 \%$ \\
\hline $\begin{array}{l}\text { To share financial } \\
\text { services (e.g. one financial } \\
\text { dept. contracting for all } \\
\text { schools) }\end{array}$ & 41 & 39 & 83 & 50 & 14 \\
\hline
\end{tabular}




\section{Stakeholder involvement in the setting evaluation standards and methodologies}

Given the lack of information relating to the evaluation of Local Education clusters in Ireland and education networks more generally, the research also sought to explore the role accorded to various stakeholders in setting evaluation standards and methodologies (Tables 8 and 9).

What emerged from the analysis was that principals were of the view that the inspectorate, teachers and principals should be the main stakeholders responsible for the development of evaluation standards and methodologies. According to one principal, 'inspectors know how to develop evaluation standards already, and principals and teachers know what works and what doesn't, the others don't'. Another principal stated, 'schools remain uniquely independent, so we need to get school leaders working together on this first'.

Principals were also of the view that other stakeholding groups, such as parents and students, should have a strictly limited role in setting evaluation methodologies and standards. As stated by one principal:

We give parents far too much say in how schools should be run. While they are a hugely important aspect of schooling, it must be noted that most parents' experience of the education system and its theory is from their own time in school. I do not expect to give my own opinions on medical research when I visit my doctor, but I feel I can be part of the solution by explaining my symptoms. A similar process should be fine.

Another said 'it's difficult to see how any profession could trust unskilled outsiders to undertake a meaningful role in systems evaluation'.

Table 8

The extent to which the following stakeholders have a say in the development of evaluation standards for the evaluation of Local Education Clusters (what is evaluated)?

\begin{tabular}{|c|c|c|c|c|c|}
\hline Stakeholder & $\begin{array}{l}\text { To no } \\
\text { extent }\end{array}$ & $\begin{array}{c}\text { To a very } \\
\text { little extent }\end{array}$ & $\begin{array}{c}\text { To some } \\
\text { extent }\end{array}$ & $\begin{array}{c}\text { To a great } \\
\text { extent }\end{array}$ & $\begin{array}{l}\text { To a very } \\
\text { great extent }\end{array}$ \\
\hline \multirow[b]{2}{*}{ The Inspectorate } & $5 \%$ & $7 \%$ & $40 \%$ & $36 \%$ & $14 \%$ \\
\hline & 10 & 13 & 78 & 71 & 27 \\
\hline \multirow{2}{*}{$\begin{array}{l}\text { Head Teachers of single } \\
\text { schools }\end{array}$} & $5 \%$ & $1 \%$ & $13 \%$ & $50 \%$ & $28 \%$ \\
\hline & 10 & 3 & 27 & 102 & 57 \\
\hline \multirow{2}{*}{$\begin{array}{l}\text { Representative of head } \\
\text { teachers }\end{array}$} & $7 \%$ & $8 \%$ & $32 \%$ & $39 \%$ & $15 \%$ \\
\hline & 14 & 15 & 64 & 76 & 29 \\
\hline
\end{tabular}




\begin{tabular}{|c|c|c|c|c|c|}
\hline Stakeholder & $\begin{array}{l}\text { To no } \\
\text { extent }\end{array}$ & $\begin{array}{c}\text { To a very } \\
\text { little extent }\end{array}$ & $\begin{array}{c}\text { To some } \\
\text { extent }\end{array}$ & $\begin{array}{c}\text { To a great } \\
\text { extent }\end{array}$ & $\begin{array}{l}\text { To a very } \\
\text { great extent }\end{array}$ \\
\hline \multirow{2}{*}{ Teachers of single schools } & $5 \%$ & $3 \%$ & $22 \%$ & $49 \%$ & $20 \%$ \\
\hline & 9 & 6 & 44 & 97 & 39 \\
\hline \multirow{2}{*}{ Representative of teachers } & $7 \%$ & $10 \%$ & $34 \%$ & $39 \%$ & $13 \%$ \\
\hline & 14 & 20 & 65 & 74 & 24 \\
\hline \multirow{2}{*}{$\begin{array}{l}\text { Governing bodies of net- } \\
\text { works }\end{array}$} & $7 \%$ & $20 \%$ & $51 \%$ & $27 \%$ & $8 \%$ \\
\hline & 12 & 35 & 87 & 47 & 14 \\
\hline \multirow{2}{*}{$\begin{array}{l}\text { Representative of govern- } \\
\text { ing bodies of networks }\end{array}$} & $9 \%$ & $22 \%$ & $43 \%$ & $29 \%$ & $11 \%$ \\
\hline & 15 & 38 & 73 & 50 & 18 \\
\hline \multirow{2}{*}{$\begin{array}{l}\text { Governing bodies of } \\
\text { single schools }\end{array}$} & $8 \%$ & $21 \%$ & $48 \%$ & $27 \%$ & $9 \%$ \\
\hline & 14 & 37 & 84 & 47 & 15 \\
\hline \multirow{2}{*}{$\begin{array}{l}\text { Representative of gov- } \\
\text { erning bodies of single } \\
\text { schools }\end{array}$} & $9 \%$ & $23 \%$ & $46 \%$ & $27 \%$ & $8 \%$ \\
\hline & 16 & 40 & 79 & 47 & 14 \\
\hline \multirow{2}{*}{ Parents } & $7 \%$ & $13 \%$ & $55 \%$ & $27 \%$ & $5 \%$ \\
\hline & 13 & 24 & 102 & 50 & 9 \\
\hline \multirow{2}{*}{ Students } & $8 \%$ & $14 \%$ & $55 \%$ & $25 \%$ & $5 \%$ \\
\hline & 14 & 26 & 101 & 47 & 9 \\
\hline \multirow{2}{*}{ Representative of parents } & $9 \%$ & $16 \%$ & $48 \%$ & $27 \%$ & $7 \%$ \\
\hline & 17 & 30 & 88 & 49 & 12 \\
\hline \multirow{2}{*}{ Representative of students } & $11 \%$ & $16 \%$ & $50 \%$ & $23 \%$ & $5 \%$ \\
\hline & 20 & 29 & 93 & 43 & 9 \\
\hline
\end{tabular}

Furthermore and with concern, given the governance structures of education networks in Ireland and other countries, only a minority of principals were of the view that governing bodies of networks and individual schools should to a great extent or higher, have a say in the development of evaluation standards and methodologies of the network. The proceeding comments illustrate this point, 'Sometimes agencies, bodies do not represent the reality in the education system'; 'some people in bodies don't always represent the people they are meant to'; 'a lot of these people you suggest only appear now and again if at all so we need people on the ground, knowing what works and what doesn't'.

We see here perhaps concerns that networks will diminish the power of schools and their leaders. 
Table 9

The extent to which the following stakeholders have a say in the development of the evaluation methodologies (how standards are evaluated)?

\begin{tabular}{|c|c|c|c|c|c|}
\hline Stakeholder & $\begin{array}{l}\text { To no } \\
\text { extent }\end{array}$ & $\begin{array}{l}\text { To a very } \\
\text { little extent }\end{array}$ & $\begin{array}{l}\text { To some } \\
\text { extent }\end{array}$ & $\begin{array}{l}\text { To a great } \\
\text { extent }\end{array}$ & $\begin{array}{l}\text { To a very } \\
\text { great extent }\end{array}$ \\
\hline \multirow{2}{*}{ The Inspectorate } & $4 \%$ & $5 \%$ & $34 \%$ & $38 \%$ & $19 \%$ \\
\hline & 8 & 9 & 68 & 75 & 38 \\
\hline \multirow{2}{*}{$\begin{array}{l}\text { Head Teachers of single } \\
\text { schools }\end{array}$} & $4 \%$ & $3 \%$ & $22 \%$ & $46 \%$ & $26 \%$ \\
\hline & 8 & 5 & 43 & 91 & 51 \\
\hline \multirow{2}{*}{ Teachers of single schools } & $4 \%$ & $3 \%$ & $27 \%$ & $45 \%$ & $21 \%$ \\
\hline & 8 & 5 & 54 & 88 & 42 \\
\hline \multirow{2}{*}{$\begin{array}{l}\text { Governing bodies of net- } \\
\text { works }\end{array}$} & $7 \%$ & $10 \%$ & $54 \%$ & $26 \%$ & $4 \%$ \\
\hline & 14 & 19 & 105 & 50 & 7 \\
\hline \multirow{2}{*}{$\begin{array}{l}\text { Governing bodies of single } \\
\text { schools }\end{array}$} & $7 \%$ & $11 \%$ & $56 \%$ & $22 \%$ & $4 \%$ \\
\hline & 13 & 21 & 110 & 44 & 8 \\
\hline \multirow{2}{*}{ Parents } & $9 \%$ & $19 \%$ & $52 \%$ & $17 \%$ & $4 \%$ \\
\hline & 17 & 38 & 102 & 34 & 7 \\
\hline \multirow{2}{*}{ Students } & $10 \%$ & $17 \%$ & $52 \%$ & $15 \%$ & $6 \%$ \\
\hline & 20 & 34 & 102 & 29 & 12 \\
\hline \multirow{2}{*}{$\begin{array}{l}\text { Representative of head } \\
\text { teachers }\end{array}$} & $8 \%$ & $8 \%$ & $32 \%$ & $37 \%$ & $15 \%$ \\
\hline & 15 & 16 & 64 & 72 & 30 \\
\hline \multirow{2}{*}{ Representative of teachers } & $7 \%$ & $9 \%$ & $32 \%$ & $37 \%$ & $14 \%$ \\
\hline & 14 & 18 & 64 & 74 & 28 \\
\hline \multirow{2}{*}{$\begin{array}{l}\text { Representative of governing } \\
\text { bodies of networks }\end{array}$} & $9 \%$ & $13 \%$ & $44 \%$ & $27 \%$ & $8 \%$ \\
\hline & 17 & 25 & 85 & 52 & 16 \\
\hline \multirow{2}{*}{$\begin{array}{l}\text { Representative of governing } \\
\text { bodies of single schools }\end{array}$} & $8 \%$ & $16 \%$ & $43 \%$ & $26 \%$ & $7 \%$ \\
\hline & 16 & 31 & 84 & 50 & 14 \\
\hline \multirow{2}{*}{ Representative of parents } & $9 \%$ & $19 \%$ & $45 \%$ & $22 \%$ & $5 \%$ \\
\hline & 18 & 37 & 89 & 44 & 10 \\
\hline \multirow{2}{*}{ Representative of students } & $11 \%$ & $17 \%$ & $46 \%$ & $21 \%$ & $5 \%$ \\
\hline & 21 & 34 & 90 & 40 & 10 \\
\hline
\end{tabular}




\section{Discussion and Conclusion}

Using Ireland as a case example, our study was guided by a number of interconnected questions; what should the priorities of education networks be, what are the benefits and challenges for such priorities and who should be involved in the development of evaluation methodologies and standards?

Overall findings suggest that participants saw many benefits to the establishment of local education clusters including collaborative learning and the potential for joint action research initiatives between local schools. On the other hand, participants were also of the view that there are many challenges relating to the varying priorities of local education clusters that need to be addressed. These issues included, but were not limited to, the need for extensive supports to ensure reciprocity among members of the network as well as clearly defined procedures to moderate the competitive tensions between schools. In summary it could be argued that, within limits, school leaders welcomed networking and were supportive to a degree. However hopes among policy makers that this degree of co-operation might extend to much desired objectives such as mobility of staff and even students across schools or cross school moderation of assessment for State examination are likely to remain beyond reach for some time to come.

Alarmingly, as with all forms of new initiatives, such as the re-introduction of school inspection in Ireland in the mid-2000s, participants were also unclear as to how local education clusters would be evaluated and who should devise the framework of quality indicators. It was suggested that inspectors, principals and teachers should have a significant role in the development of these instruments. However, worryingly, given the school and network governance structures that exist in Ireland, principals did not see any significant need for governing bodies of schools and networks to be involved in the development of evaluation methodologies and standards. By way of association, participants were also of the view that a road map for education clusters together with a loosely bound framework of quality indicators to evaluate the quality of network activities would be welcomed. To truly harness the potential for educational networks, participants were also of the view that local education clusters should be allowed to decide what aspect of educational provision they would like to collectively improve as opposed to that which is dictated by the architects of policy and practice, namely politicians and civil servants.

In conclusion, Hargreaves and Fullan (2012) in reference to the 'professional capital agenda' advise that, 'teachers are at the heart of the quality agenda, but we have demonstrated that this matter is being horribly stereotyped as policymakers in more and more countries opt for individualistic, competitive, and coercive solutions through a combination of sticks and carrots' (p.149). In agreement and as evidenced throughout the history of educational reform; if teachers are not at the very heart of mapping out any new initiative, terms such as 'initiative overload', 'competition' and 'stress' as opposed to 'equity', 'fairness' and 'innovation' will undeniably be used as sedentary oppositions to innovation and change, as was the case with many participants involved in this research. 


\section{References}

Azorín, C. M., \& Muijs, D. (2017). Networks and collaboration in Spanish education policy. Educational Research, 59(3), 273-296. doi: 10.1080/00131881.2017.1341817

Barber, M., Chijioke, C., \& Mourshed, M. (2010). Education: How the world's most improved school systems keep getting better. London: McKinsey \& Company.

Brown, M., McNamara, G., \& O'Hara, J. (2015). School Inspection in a Polycentric Context: The case of Northern Ireland. Dublin: EQI.

Centre for School Leadership (2018a). Excellence through Collaborative Leadership and Management. Retrieved from: https://www.cslireland.ie/leadership-clusters.html

Centre for School Leadership (2018b). Application Form for Clusters. Retrieved from: https://www.cslireland.ie/leadership-clusters.html

Centre for School Leadership (2018c). Excellence through Collaborative Leadership and Management. Retrieved from: https://www.cslireland.ie/leadership-clusters.html

Chapman, C. (2008). Towards a framework for school-to-school networking in challenging circumstances. Educational research, 50(4), 403-420. doi: 10.1080/00131880802499894

Chapman, C, \& Hadfield, M. (2009). Leading school-based networks. London: Routledge.

Chapman, C., \& Hadfield, M. (2010). Realising the potential of school-based networks. Educational research, 52(3), 309-323. doi: 10.1080/00131881.2010.504066

Creswell, J. W., \& Clark, V. L. P. (2017). Designing and conducting mixed methods research. London: Sage Publications.

Daly, A., \& Finnigan, K. (2012). Exploring the space between: Social networks, trust, and urban school district leaders. Journal of School Leadership, 22(3), pp. 493-530. doi: 10.1177/105268461202200304

Department of Education and Skills (2018a). Schools funded to work together on Experimental Projects, as Minister Bruton rewards Excellence \& Innovation [Press release]. Retrieved from https://www.education.ie/en/Press-Events/Press-Releases/2018press-releases/PR2018-04-02.html

Department of Education and Skills (2018b). A Short Guide to the areas of provision and the services supported by Teacher Education Section. Retrieved from:

https://www.education.ie/en/Education-Staff/Information/-New-Teachers/TeacherEducation-Section-A-Short-Guide.pdf

Díaz-Gibson, J., Civís, M., Daly, A. J., Longás, J., \& Riera, J. (2017). Networked leadership in educational collaborative networks. Educational Management Administration E Leadership, 45(6), 1040-1059. doi: 10.1177/1741143216628532

Department of Education and Skills [Ireland]. (2012). Circular 0040/2012. Dublin: Department of Education and Skills.

Ehren, M. C., \& Godfrey, D. (2017). External accountability of collaborative arrangements; a case study of a Multi Academy Trust in England. Educational Assessment, Evaluation and Accountability, 29(4), 339-362. doi: 10.1007/s11092-017-9267-z

Ehren, M. Janssens, F., Brown, M., McNamara, G., O'Hara, J. \& Shevlin, P. (2017). Evaluation and decentralised governance: the case of inspections in polycentric education systems. Journal of Educational Change, 18(3), 365-383. doi: 10.1007/ s10833-017-9297-9 
Glazer, J. \& Peurach, D. (2013). School Improvement Networks as a Strategy for Large-Scale Education Reform The Role of Educational Environments. Educational Policy, 27(4), 676-710. doi: 10.1177/0895904811429283

González, A., Pino, M. \& Ahumada, L. (2017). Transitar desde el mejoramiento escolar al mejoramiento sistémico: Oportunidades y desafíos de las redes escolares en Chile. Chile: Centro de Liderazgo para la Mejora Escolar.

Goodall, J, Day, C, Lindsay, G, Muijs, D \& Harris, A. (2005). Evaluating the Impact of Continuing Professional Development. vol. Research Report RR659, Department for Education.

Government of Ireland (2018). Empowering through learning. Action Plan for Education 2019. Retrieved from: https://www.education.ie/en/Publications/CorporateReports/Strategy-Statement/action-plan-for-education-2019.pdf

Hargreaves, A., \& Fullan, M. (2012). Professional capital: Transforming teaching in every school. New York: Teachers College Press.

Janssens, F. J., \& Ehren, M. C. (2016). Toward a model of school inspections in a polycentric system. Evaluation and program planning, 56, 88-98. doi: 10.1016/j.evalprogplan.2016.03.012

Katz, S., \& Earl, L. (2007). Creating New Knowledge: Evaluating Networked Learning Communities. Education Canada, 47(1), 34-37.

Lawlor, A. (2014). Transitions Toward Transformation: Exploring Continuing Professional Development for Teachers in Ireland (2 Vols.). Doctoral dissertation, National University of Ireland Maynooth.

Lieberman, A., \& McLaughlin, M. W. (1992). Networks for educational change: Powerful and problematic. Phi delta kappa, 73(9), 673.

McCormick, R., Fox, A., Carmichael, P., \& Procter, R. (2010). Researching and understanding educational networks. London: Routledge.

Miles, M. \& Huberman, A. (1994). Qualitative data analysis: An expanded source book ( $2^{\text {nd }}$ ed.). Thousand Oaks, CA: Sage.

Morgan, D., \& Cook, B. (2015). New public governance: A regime-centered perspective. London: Routledge.

Muijs, D., West, M., \& Ainscow, M. 2010. Why network? Theoretical perspectives on networking. School Effectiveness and School Improvement, 21(1), pp. 5-26.

Moolenaar, N. (2010). Ties with potential. Nature, antecedents, and consequences of social networks in school teams. PhD thesis, University of Amsterdam.

OECD (2015). Improving schools in Scotland: an OECD perspective. Paris: OECD Publishing.

OECD (2012). Equity and Quality in Education: Supporting Disadvantaged Students and Schools. Paris: OECD Publishing.

OECD (2019). Making Decentralisation Work: A Handbook for Policy-Makers. Paris: OECD Publishing.

Prenger, R., Poortman, C. L., \& Handelzalts, A. (2018). The Effects of Networked Professional Learning Communities. Journal of Teacher Education. doi: 0022487117753574.

Provan, K. G., \& Kenis, P. (2008). Modes of network governance: Structure, management, and effectiveness. Journal of public administration research and theory, 18(2), 229-252. doi: 10.1093/jopart/mum015 
Rincón-Gallardo, S., \& Fullan, M. (2016). Essential features of effective networks in education. Journal of Professional Capital and Community, 1(1), 5-22. doi: 10.1108/ JPCC-09-2015-0007

Sammons, P., Mujtaba, T., Earl, L., \& Gu, Q. (2007). Participation in network learning community programmes and standards of pupil achievement: Does it make a difference? School Leadership and Management, 27(3), 213-238. doi: 10.1080/13632430701379412

Smith, A. K., \& Wohlstetter, P. (2001). Reform through school networks: A new kind of authority and accountability. Educational policy, 15(4), 499-519. doi: 10.1177/0895904801015004001

Teacher Professional Networks (2017). What is the Teacher Professional Networks Scheme (TPN)? Retrieved from: http://www.tpnetworks.ie/

Wenger, E. (1998). Communities of practice: Learning, meaning and identity. Cambridge: Cambridge University Press.

Wenger, E. (2000). Communities of practice and social learning systems. Organization, $7(2), 225-246$.

Wohlstetter, P., Malloy, C. L., Chau, D., \& Polhemus, J. L. (2003). Improving schools through networks: A new approach to urban school reform. Educational Policy, 17(4), 399-430.

Fecha de recepción: 29 de septiembre de 2019.

Fecha de revisión: 21 de octubre de 2019.

Fecha de aceptación: 29 de octubre de 2019. 